\title{
Changes of gonadotropin-releasing hormone receptor 2 during the anadromous spawning migration in Coilia nasus
}

\author{
Jin-Rong Duan ${ }^{1+}$, Di-An Fang ${ }^{1 \dagger}$, Min-Ying Zhang ${ }^{1+}$, Kai Liu' ${ }^{1}$, Yan-Feng Zhou ${ }^{1}$, Dong-Po Xu ${ }^{1}$, Pao Xu ${ }^{1 *}$ \\ and Da-Peng $\mathrm{Li}^{2^{*}}$
}

\begin{abstract}
Background: An increase in the activity of the pituitary-gonad axis (PG-axis) and gonad development are essential for the onset of spawning migration in teleosts. In the fish Coilia nasus, gonad development and spawning migration up the Yangtze River occurs by the end of each summer. We hypothesized that gonadotropin releasing hormones receptor 2 (GnRH-R2), which together produce a signal that interacts with the PG-axis, may help to regulate spawning migration processes.

Results: In this regard, we (1) characterized the gonadosomatic index (GSI) in the anadromous fish C. nasus; (2) analyzed the GnRH-R2 mRNA expression levels in ovary and brain, and concentrations in the serum; and (3) identified the GnRH-R2 protein distribution in the brain and ovaries. We found strong relationships between all of these indices.

Conclusions: The results indicate that GnRH-R2 could act together to promote spawning during the anadromous migration. There is some evidence that the GnRH-R2 gene expression levels and protein distributions change in association with the migratory behavior.
\end{abstract}

Keywords: GnRH-R2, Spawning upstream migration, Coilia nasus, Yangtze River

\section{Background}

Gonad maturation and spawning migration in teleosts are primarily regulated by pituitary-gonad axis (PG) neurohormones $[1,2]$. The hypothalamic neutrohormone, gonadotropin-releasing hormone $(\mathrm{GnRH})$, helps to regulate gonad function and spawning migration behaviors in fish [3-6]. GnRH stimulates the synthesis and release of pituitary gonadotropins, including follicle stimulating hormone and luteinizing hormone; these hormones then stimulate spawning behavior $[7,8]$. Analyses of how $\mathrm{GnRH}$ is involved in spawning processes are complicated, because there are multiple forms of $\mathrm{GnRH}$ in the brains of some fish species [9-11]. In

\footnotetext{
* Correspondence: xup@ffrc.cn; Idp@mail.hzau.edu.cn

${ }^{\dagger}$ Equal contributors

${ }^{1}$ Freshwater Fisheries Research Center, Chinese Academy of Fishery Sciences, 9 Shanshui Road, Wuxi 214128, China

${ }^{2}$ Key Laboratory of Freshwater Animal Breeding, Ministry of Agriculture, Huazhong Agricultural University, Wuhan 430070, China
}

association with the different forms of $\mathrm{GnRH}$, there are multiple forms of $\mathrm{GnRH}$ receptors (GnRH-Rs); these receptors bind to $\mathrm{GnRH}$, initiating the intracellular signaling system $[9,12]$. GnRHs and GnRH-Rs have also been found in gonads of fish [13, 14].

GnRH-Rs were first cloned from mouse pituitary cells $[15,16]$. The first non-mammalian GnRH-Rs were obtained from African catfish [17]. However, even though nearly 30 years have passed, in fish species, the distribution of GnRH-Rs in cells and tissues, their regulation, and their functions remain elusive. By characterizing GnRH-R expression levels, we could improve understanding of the physiological consequences of $\mathrm{GnRH}$ stimulation [18]. In addition, the characterization of GnRH-R gene expression in a single species would help to clarify the mechanisms that regulate GnRH functions [19]. Most studies on GnRH-Rs have focused on the pituitary gland and few have considered the gonads. For 
example, the stimulation of GnRH both up- and downregulated the GnRH-Rs in the pituitary gland [12]. Thus, little is known about the regulation of GnRH-Rs in the gonads.

Coilia nasus (Clupeiformes: Engraulidae), the Japanese grenadier anchovy, is a small-moderate sized fish [20-22]. C. nasus is an anadromous species; every year it migrates from the sea up to the middle and lower reaches of rivers in China, including the Yangtze River, and the lakes connected to it $[21,23]$. C. nasus reaches sexual maturity at 2-3 years old. It lays eggs from March to July, breeding once a year [24]. C. nasus provides a classic case-study for yearly spawning behavior, with migration distances that reach thousands of miles [20,25].

Changes in the aquatic ecology of the Yangtze River almost caused extinction of $C$. nasus in its middle reaches $[26,27]$. As a result, attempts have been made to alleviate the threat to C. nasus resources [28]. Several research projects into artificial breeding and larval rearing techniques have been done $[28,29]$. However, these studies have been limited to the biological characteristics and genetic diversity of the species [30-33]. The endocrine mechanisms involved in regulating migration and spawning in C. nasus have not been considered, to our knowledge.

To investigate the role of GnRH-Rs play in regulating fish spawning migration and gonadal maturation, we analyzed changes in the gonadosomatic index (GSI \%) and used enzyme-linked immunosorbent assays (ELISAs) to test serum concentrations of GnRH-R2 during different spawning stages. Furthermore, we cloned the GnRH-R2 gene in $C$. nasus and examined their expression patterns in the brain and ovary using real-time quantitative PCR (RTqPCR). The GnRH-R2 protein distributions were also identified, in both the brain and ovary, using immunohistochemistry (IHC). The present study enabled us to understand the function of GnRH-R2 in C. nasus, in association with the onset and development of spawning migration in the species.

\section{Methods}

\section{Fish sampling}

In 2015, from March to August, healthy fish $(n=98)$ from six populations of $C$. nasus, were collected at seven time points from their major regional habitats in the Yangtze River during their migration upstream (Fig. 1). The collection sites were at: Anqing (AQ); Dangtu (DT); Zhenjiang (ZJ); Jingjiang (JJ); Nantong (NT), and Chongming $(\mathrm{CM})$. Fish were kept on dry ice immediately after collection, and were transferred to the laboratory in the dry ice boxes.

\section{Analysis of development stage and tissue collection}

After measuring the body weights (BW $\pm 0.01 \mathrm{~g}$ wet weight; WW) of the fish their gonads were dissected and their genders were determined; only female fish (total 98 individuals,14 fish per time point) were studied for GSI analysis. The gonad weight $(\mathrm{GW} \pm 0.01 \mathrm{~g}$ WW) were recorded so that the GSI of each fish could be calculated $(\mathrm{GSI}=\mathrm{GW} / \mathrm{BW} \times 100)$ for each population (mean \pm standard deviation).

Based on visual judgment of the gonads and microscopic examination of the oocytes, each female was assigned to one of the following seven stages of oocyte development [34]: onset stage (stage I; fish collected in March), developmental stage (stage II; April), multiplication stage (stage III; May), mature stage (stage IV; June), spawning stage (stage V; late June), spawned stage (stage VI; July), or rest stage (stage VII; August). All fish experimental procedures were performed according to the Regulations for the Administration of Affairs Concerning Experimental Animals approved and authorized by the State Council of People's Republic of China.

\section{RNA extraction}

During dissection, the brain and ovary tissues from individuals at each oocyte development stage $(n=5)$ were selected randomly for RNA extraction and the extracts were pooled to form one sample for mRNA expression analysis. Total RNA was extracted using Trizol Lysis Reagent and then purified with an RNA easy kit (Invitrogen, Beijing, China), according to the manufacturer's instructions. The RNA integrity and quantity were estimated by spectrophotometry (absorbance at $260 \mathrm{~nm}$ ) and agarose gel electrophoresis, respectively.

\section{RTqPCR analysis}

To analyze the mRNA transcript expression patterns at each fish developmental stage, total RNA (about $2 \mu \mathrm{g}$ ) that had been isolated from the brains and ovary tissues was reverse transcribed into cDNA using the SMART ${ }^{\mathrm{TM}}$ cDNA kit (Clonetech, USA) and RTqPCR analysis was performed, using the PrimeScript Real-time PCR Kit (TaKaRa, Japan). Target fragments of cDNA that encode GnRH-R2 were chosen basing on the constructed transcriptome library using BLAST tool [35]. First-strand cDNA was prepared as described above; the genespecific primer pair (GnRH-R2-F and GnRH-R2-R; Table 1) were designed based on the cDNA sequences (GenBank accession numbers KU861569) to produce $387 \mathrm{bp}$ amplicons. The PCR reaction conditions were as per the qPCR Kit protocol. Samples were run in triplicate using pooled RNA (as described above) at the same concentration, and normalized to the selected control gene18sRNA; the primer pair 18sRNA-R and 18sRNA-F (Table 1) were designed based on the C. nasus 18sRNA and to amplify a fragment of $232 \mathrm{bp}$. The gene expression levels were calculated using the $2^{-\Delta \Delta \mathrm{Ct}}$ comparative CT method [36]. Mean and standard deviation values 


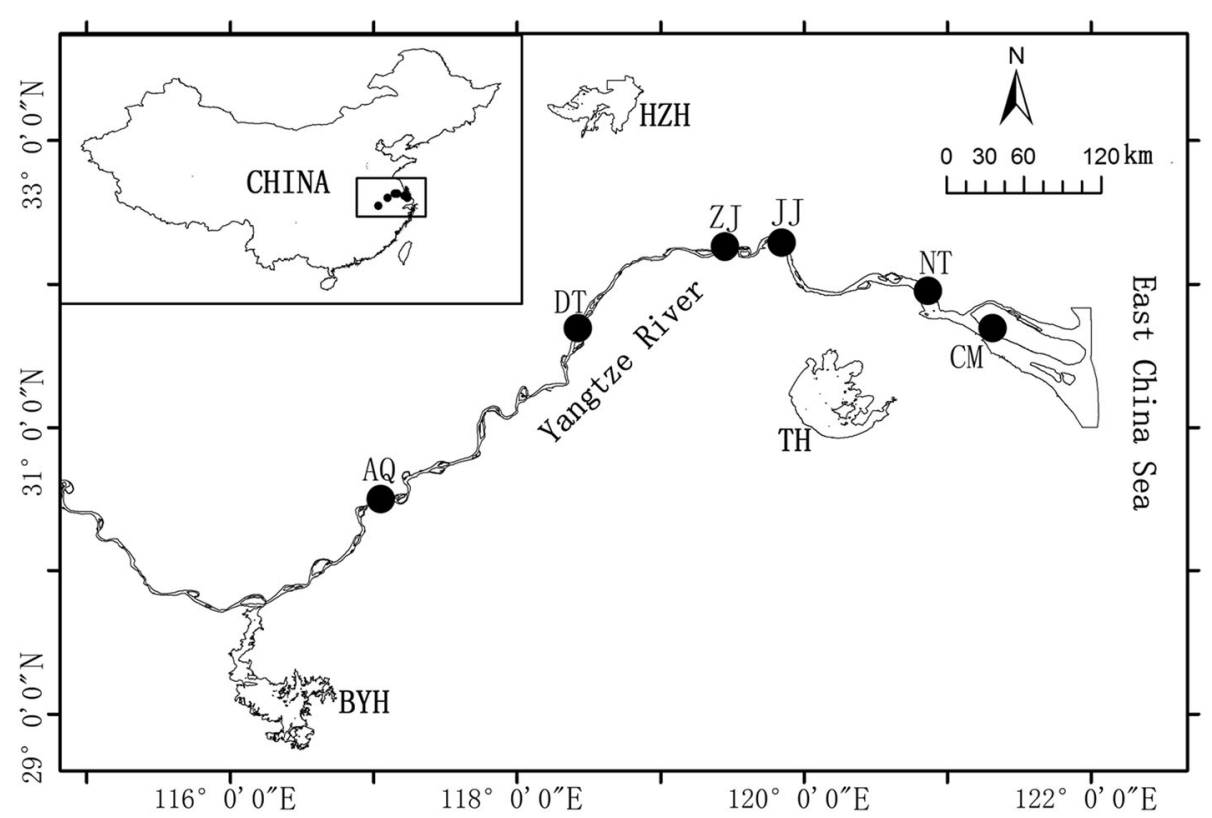

Fig. 1 Sampling distribution locations for C. nasus in the Yangze River. Black dot display the sampling distribution locations. AQ: Anqing; DT: Dangtu; ZJ: Zhenjiang; JJ: Jingjiang; NT: Nantong; CM: Chongming, TH: Taihu lake; HZH: hongzehu lake; BYH: Boyanghu lake

were calculated from the triplicate runs, and presented as fold differences in expression, relative to $18 \mathrm{~s}$ RNA expression. Data were analyzed using CFX Manager ${ }^{\text {TM }}$ software (version 1.0).

\section{GnRH-R2 antiserum preparing}

GnRH-R2 antiserum was produced commercially by Hua-an Biol. Co., Ltd. (Hua-an, Hangzhou, China). Briefly, a synthetic signature peptide (LVVVSLDRH) for GnRH-R2, conjugated with the keyhole limpet hemocyanin, was emulsified with complete (for the first immunization) and incomplete (for the second to fourth immunizations) Freund's adjuvant, and injected into a New Zealand rabbit at intervals of 2 to 3 weeks. Before immunization and after the third and fourth injections, the rabbit was bled and serum samples were collected.

Table 1 Sequences of primers used in the present study

\begin{tabular}{|c|c|c|c|}
\hline $\begin{array}{l}\text { Primer Name } \\
\text { F-Forward/ } \\
\text { R-Reverse }\end{array}$ & DNA-Sequence 5'-3' & $\begin{array}{l}\text { Annealing } \\
\text { Temperature }\left({ }^{\circ} \mathrm{C}\right)\end{array}$ & $\begin{array}{l}\text { Fragment } \\
\text { Size (bp) }\end{array}$ \\
\hline \multicolumn{4}{|c|}{ Gene-specific Primer pairs for RT-qPCR } \\
\hline GnRH-R2-F & $\begin{array}{l}\text { 5'-CGTGCGGTGAAGG } \\
\text { CGAAGGGGGTGG-3' }\end{array}$ & 60.7 & 387 \\
\hline GnRH-R2-R & $\begin{array}{l}\text { 5'-ACACAACCCCAAC } \\
\text { TAAGCAAGCATA-3' }\end{array}$ & 64.7 & \\
\hline \multicolumn{4}{|c|}{ 18sRNA primers } \\
\hline 18sRNA-R & $\begin{array}{l}\text { 5'- TGATTGGGACTGG } \\
\text { GGATTGAA-3' }\end{array}$ & 59.2 & 232 \\
\hline 18sRNA-F & $\begin{array}{l}\text { 5'- TAGCGACGGGC } \\
\text { GGTGTGT-3' }\end{array}$ & 62.4 & \\
\hline
\end{tabular}

An increase in antibody titers against the peptide was verified by enzyme-linked immuno sorbent assay (ELISA).

\section{ELISA}

ELISAs were used to measure the GnRH-R2 concentrations in the fish serum. Re-GnRH-R2 were diluted in $50 \mathrm{mM}$ carbonate buffer ( $\mathrm{pH} 9.6$ ), to produce concentrations of $30 \mathrm{ng} / \mathrm{mL}$ and $40 \mathrm{ng} / \mathrm{mL}$, respectively. Ninety-six well polystyrene plates were coated with $50 \mu \mathrm{L}$ per well of re-GnRH-R2 solution overnight at $4{ }^{\circ} \mathrm{C}$. The wells were then washed three times with phosphate-buffered saline (PBS) containing $0.05 \%$ Tween20 (TPBS). Then, $100 \mu \mathrm{L}$ of Superblock in PBS was put into each well for $1 \mathrm{~h}$ at room temperature (RT) before the antigen-coated plate was washed with PBS again.

Serum samples ( $n=6$ for each development stage) from C. nasus were diluted 1:8 with TPBS. TPBS with $5 \%$ goat serum was used to dilute the primary antibodies (anti-GnRH-R2) at a ratio of 150:1. In $1.5 \mathrm{~mL}$ microtubes, each sample and standard was mixed with equal amounts of each primary antibody (separately). $50 \mu \mathrm{L}$ of each reaction mixture was dispensed into separate wells on the antigen-coated plate in triplicate. The plate was incubated at $4{ }^{\circ} \mathrm{C}$ overnight.

After incubation, $50 \mu \mathrm{L}$ of solution containing biotinylated antibody to rabbit immunoglobulins (Zymed, CA, USA) diluted at a ratio of 1:10 in $5 \%$ NGS-TPBS, was allotted to each well for $1.5 \mathrm{~h}$ at RT. The wells were then washed and further incubated, for $1 \mathrm{~h}$ at RT with $50 \mu \mathrm{L}$ (per well) of streptavidin-polyHRP80 (Fitzgerald, CA, USA) diluted into $200 \mathrm{ng} / \mathrm{mL}$ with Universal Casein 
Diluent/Blocker. The wells were washed again and then $100 \mu \mathrm{L}$ of 1-Step Ultra TMB-ELISA solution (Thermo Scientific, Waltham, USA) was dispensed into each well for development for 30-60 min at RT. The reaction was stopped by adding $100 \mu \mathrm{L}$ of $2 \mathrm{M}$ sulfuric acid. Absorbance was read at $450 \mathrm{~nm}$.

The optical density results of the pooled serum samples' serial dilutions and those of the standards were used to validate the serum GnRH-R2 levels. The optical densities of related substances (including glycoprotein hormones and their subunits) were compared with those of the standards to analyze the specificity of the experiments. The precision of the assays was assessed from the intra-and inter-assay coefficients of variation $(\mathrm{CV})$ from the same samples. The concentration of GnRHR2 in the samples was calculated from the standard curve, constructed using the optical densities of the standards in ELISA analysis software (Magellan, Tecan, Männedorf).

\section{IHC}

During dissection, sexually mature individuals $(n=3$, stage IV) were selected for the IHC experiment. Ovaries were fixed in $0.01 \mathrm{M}$ PBS containing $4 \%$ paraformaldehyde and stored at $4{ }^{\circ} \mathrm{C}$ overnight. After washing with PBS three times, ovaries were dehydrated in $20 \%$ saccharose-PBS solution for $4 \mathrm{~h}$ at RT. Then they were embedded in organ optimal cutting temperature compound (Sakure, CA, USA). Standard frozen sections ( $8 \mu \mathrm{m}$ in thickness) were taken using a microtome (Leica, Bensheim, Germany). Then, after washing with $0.01 \mathrm{M}$ PBS three times (each wash, $10 \mathrm{~min}$ ), the sections were immersed in $0.01 \mathrm{M}$ citric acid buffer (pH 6.0) containing $0.1 \%$ Tween 20, and autoclaved for 5 min. Following this, a blocking solution (Roche, Shanghai, China) was used to treat the sections. AntiGnRH-R2 (1:200) was added to the sections and then they were incubated overnight at $4{ }^{\circ} \mathrm{C}$, then rinsed with $0.01 \mathrm{M}$ PBS three times (each wash, $5 \mathrm{~min}$ ). Then goat anti-rabbit IgG conjugated with horseradish peroxidase were added and the sections were incubated for $30 \mathrm{~min}$, before being rinsed with PBS three times (each wash, $5 \mathrm{~min}$ ). Diaminobenzidine (Sigma, Shanghai, China) was used as the substrate to visualize the immunoreactive signals and the sections were counterstained with $\mathrm{H}$ \& E. As a negative control, organ sections were also incubated with pre-immune rabbit serum and blocking solution.

\section{Statistical analysis}

A multiple comparisons (Duncan's) test was used to compare differences in GSI, GnRH-R2 concentrations in the serum, and gene expression in the ovary and brain tissue, among the control and tested samples $(P<0.05)$.

\section{Results}

In total, 98 C. nasus female fish (14 per time point) were sampled from the onset migration stage to the rest stage (from March to August, 2015) for the GSI analysis (Fig. 2). During March and April (stages I and II), the female fish GSI was very low ( $<1.0 \%$, Fig. 2$)$. In May (stage III), the GSI increased slightly, but significantly (GSI $=1.59 \%$ ); in June (stage IV), the female GSI increased sharply (GSI = 5.12, $P<0.05)$ and this increase continued into late June (stage V), when the highest GSI was recorded, during the spawning stage (GSI $=10.09 \%)$. After the spawning stage (in July, stage VI), the GSI decreased sharply in the spawned stage $(\mathrm{GSI}=0.71 \%)$ and was at very low levels, similar to those in March and April, for the rest stage in August (GSI $=0.65 \%$ ).

The GnRH-R2 concentration in the serum during the migration stages of the fish changed interestedly (Fig. 3). There was a gradual increase in the serum GnRH-R2 concentrations from the onset (stage I) to multiplication (stage III), and then a sharp increase to the highest concentration of GnRH-R2 observed during maturation (stage IV); after the mature stage, significantly high levels (though not as high as in stage IV) of GnRH-R2 were maintained during the spawning and spawned stages (stage $\mathrm{V}$ and $\mathrm{VI}$ ), and then there was a sharp decrease for the rest stage.

The temporal expression levels of the GnRH-R2 mRNA transcripts in the brain and ovary during the migration cycle are presented in Fig. 4. The GnRH-R2 mRNA transcription (Fig. 4) were maintained high levels during the migration stages (from stage II in April to stage VI in July) in both the brain and ovaries. Interestingly, three peaks in GnRH-R2 mRNA transcription within the ovaries were observed during that time period: one in the developmental stage (stage II; April), the second in the maturation stage (stage IV; June) and the third peak was in the spawned stage (stage VI; July). GnRH-R2 mRNA transcription in the brain peaked in the multiplication stage (stage III; May). Higher expression levels $(P<0.05)$ were detected in the ovary from the developmental stage to the rest stage (April-August).

The whole section of the brain and ovary, stained with hematoxylin-eosin ( $\mathrm{H} \& \mathrm{E})$ and with anti-GnRH-R2 immunolabeling (counterstained with $\mathrm{H} \& \mathrm{E}$ ), from the IHC analysis, are shown in Fig. 5. Immunoreactive positive signals for the GnRH-R2 protein were detected; in the brain and ovary tissues, the positive signals for GnRH-R2 were mainly found in the cytoplasm of olfactory bulb (OB) cells, stratum granulare (SG) cells and in oocytes at different developmental stages. The strongest signals were found in the primary oocytes; lower positive signals were found in the cytoplasm of $\mathrm{OB}$ and SG cells; and weak signals or an absence of any signal were observed in the mature oocytes and 


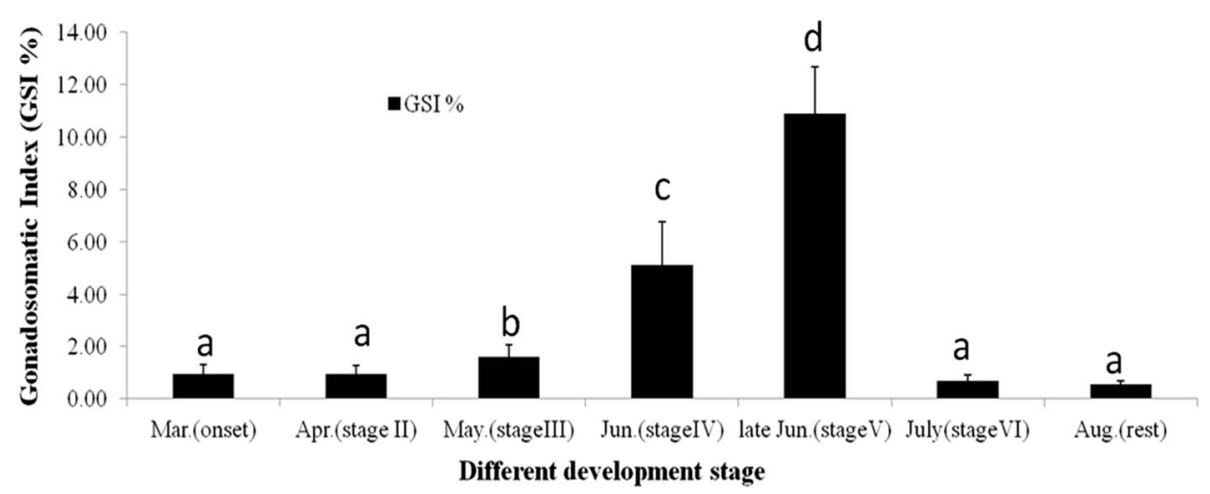

Fig. 2 Changes in the gonadosomatic index (GSI) during the oocyte development stages in Coilia nasus. The stages were defined as: onset stage (stage I; fish collected in March), developmental stage (stage II; April), multiplication stage (stage III; May), mature stage (stage IV; June), spawning stage (stage V; late June), spawned stage (stage Vl; July), and rest stage (stage VIl; August). Data are expressed as the mean \pm SE $(n=7$ for each stage). Columns with different letters above them are significantly different $(P<0.05, a<b<c<d)$

neurogliocyte cells. No positive signals were observed in the negative control, which was incubated with the pre-immune rabbit serum (Fig. 5).

\section{Discussion}

There were significant differences in the GSI among the different oocyte developmental stages of the anadromous female fish $C$. nasus. Usually, in late March $C$. nasus begins spawning, moving upstream between the Chongming and Anqing sections of the Yangtze River, and then the fish enter into their resting stage [24]. After a short time of recruitment, the fish then begin to migrate downstream and into the sea, finishing the migration spawning cycle [34]. The females' GSI levels were very low in the onset and development stages; these fish were mainly recruiting and their gonads were just beginning to start development. From May to early July, the GSI levels significantly increased, as the fish spawned in the upstream reaches of the river. During the spawning stage, when the fish were located upstream, ovaries were physically stimulated for further development, growing bigger and the GSI increasing, accordingly, until the fish had spawned.

To investigate the trigger of ovary maturation and spawning migration in C. nasus, we measured the serum GnRH-R2 concentration. The serum GnRH-R2 concentration was at its maximum in June (mature stage) and was maintained at high concentration during late June (spawning stage) and when they had just spawned in July. Similar in the protandrous black porgy fish, Acanthopagrus schlegeli, the expression profiles of both forms of GnRH-R were variable in the gonads according to the gonadal stage and season [13]. Combing with our findings for $C$.nasus, the results indicated that the high GnRH-R2 level may have been a biological response to migration/spawning behavior [13, 37]. Furthermore, the

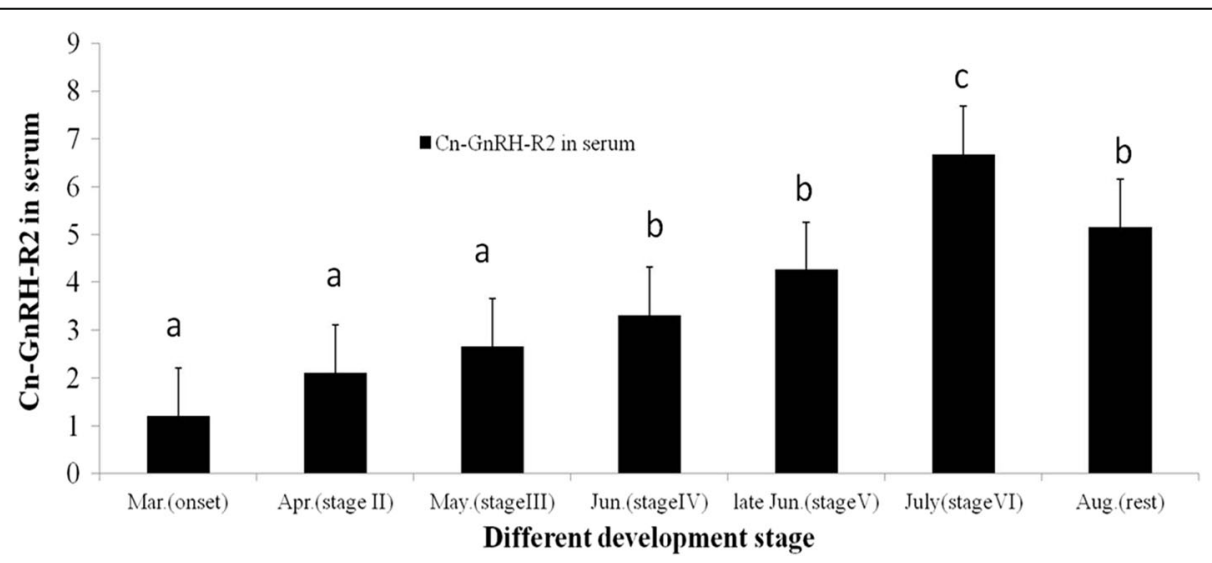

Fig. $3 \mathrm{GnRH}-\mathrm{R} 2$ concentration in serum during the oocyte development stage in Coila nasus. The stages were defined as: onset stage (stage l; fish collected in March), developmental stage (stage II; April), multiplication stage (stage III; May), mature stage (stage IV; June), spawning stage (stage V; late June), spawned stage (stage Vl; July), and rest stage (stage VIl; August). Data were collected by enzyme-linked immunosorbent assays and are expressed as the mean \pm SE $(n=3)$. Columns with different letters above them are significantly different $(P<0.05, a<b<c)$ 


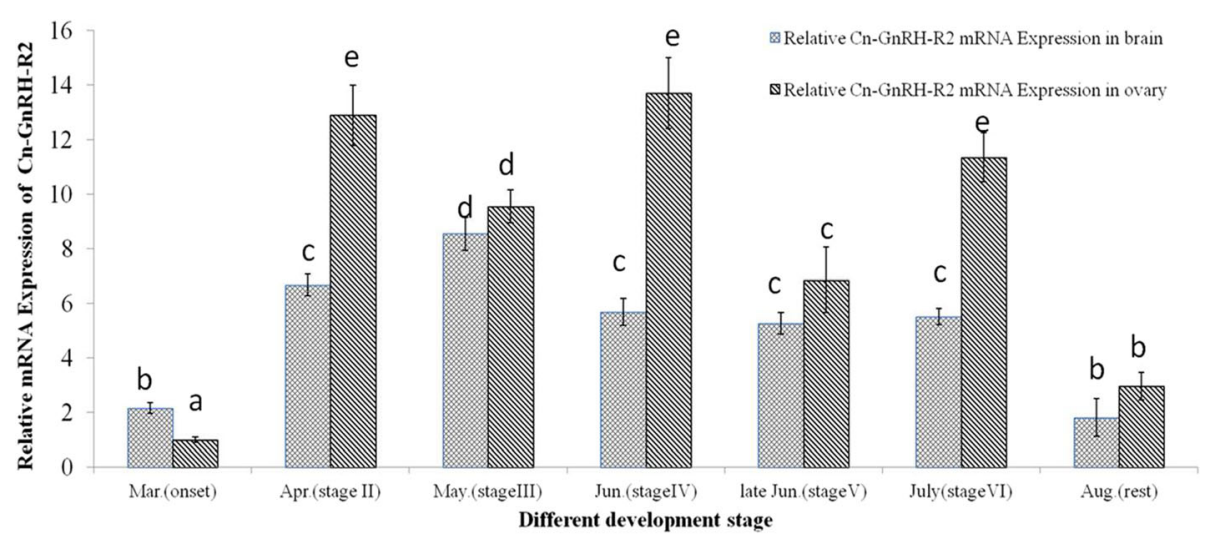

Fig. 4 Changes in expression of GnRH-R2 mRNA in brain and ovary tissues during the oocyte development stage in Coila nasus. The stages were defined as above. Expression values were normalized to those of 18sRNA. Data are expressed as the mean fold difference (mean $\pm \mathrm{SE}, n=3$ ) compared to the 18sRNA expression. Columns with the different letters above them are significantly different $(P<0.05, \mathrm{a}<\mathrm{b}<\mathrm{c}<\mathrm{d}<\mathrm{e})$
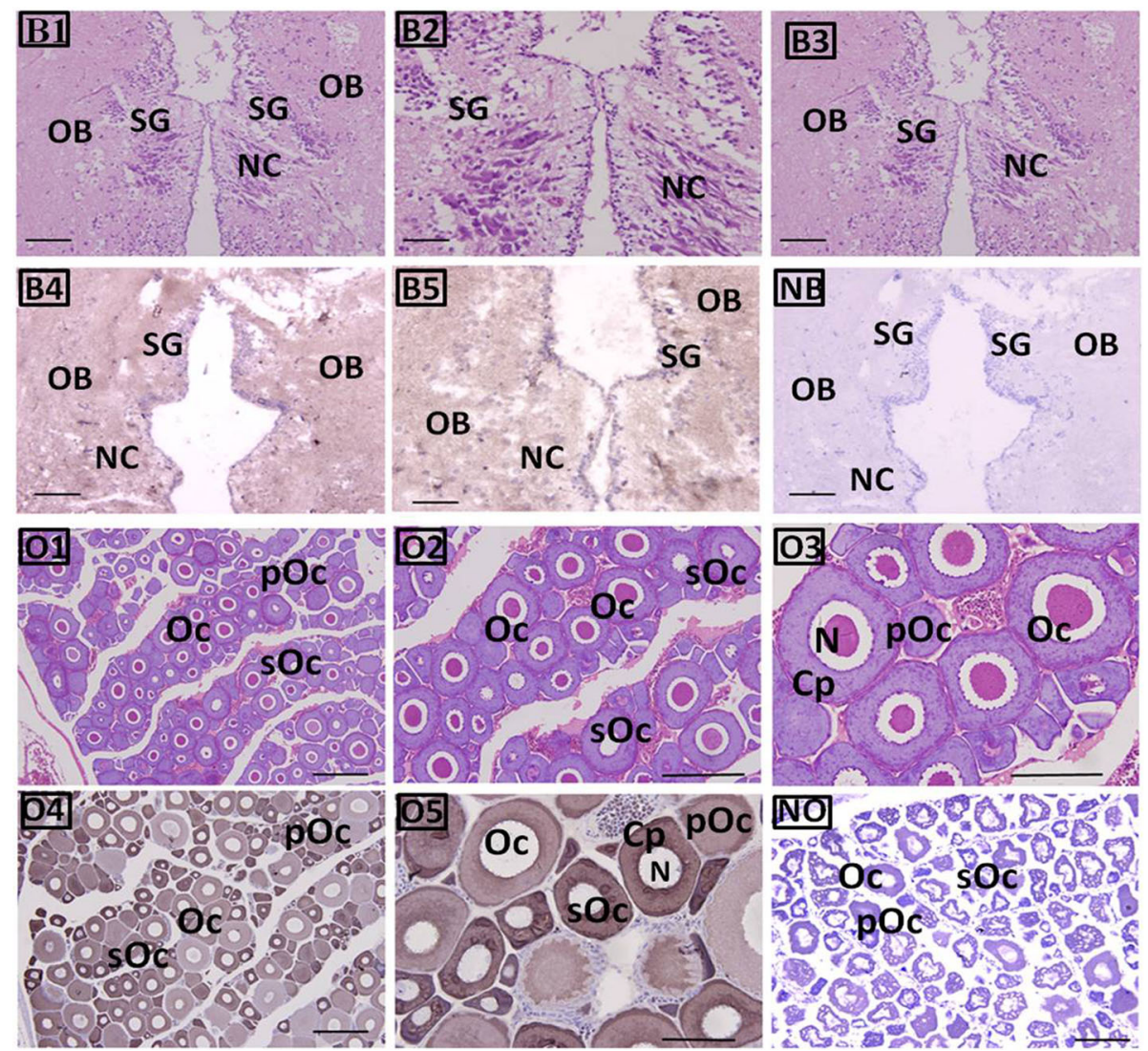

Fig. $5 \mathrm{GnRH}-\mathrm{R} 2$ locations in the brain and ovary tissues. Immunohistochemical positive signals of GnRH-R2 immunolabeling are shown in brown. B1-B3: whole brain sections stained with H\&E; B4-B5: GnRH-R2 immunolabels in different parts of the brain; and NB: negative control for brain. O1-O3: whole ovary sections stained with H\&E; O4-O5: GnRH-R2 immunolabels in different parts and oocyte developmental stages of the ovary for IHC (O5 provides a more magnified view of the ovary IHC signal); and NO: negative control for the ovary tissue. Key: OB, olfactory bulb; SG, stratum granulare; NC, Neurogliocyte, pOc, primary oocyte; sOc, secondary oocyte; Oc, oocyte; N, oocyte nucleus; and Cp, oocyte cytoplasm. Scale bar = $100 \mu \mathrm{m}$ 
high level of GnRH-R2 in the serum during the different stages of oocyte development could demonstrate their crucial role in regulating the spawning migration.

During the migration period, the GnRH-R2 mRNA transcripts were preferentially expressed in the brain and ovary tissues; mRNA expression levels were closely related to the different migration stages. The GnRH-R2 mRNA expression levels in the brain were significantly high, which indicates that it would play a dominant role in regulating migration/spawning behavior [37]. GnRH-R2 mRNA expression levels significantly increased over time during the $C$. nasus migration cycle, which may be related to maintaining high GnRH mRNA levels during the mature oocyte stage. Overall the GnRH-R2 mRNA expression levels changed quite similarly during the spawning period, indicating that GnRH-R2 would be closely involved in ovary maturation and migration behavior in $C$. nasus. The mRNA expression patterns at the different oocyte development stages in $C$. nasus were inconsistent with those observed in farmed salmon [11], the amounts of GnRH-R2 mRNA in the forebrain, were high between winter and spring, in the prepubertal stages, then declined as summer approached, and finally increased again in the spawning season [38]. According to the salmon, since the maturing $C$. nasus leave the East Sea for the egg laying sites in the Yangtze River, gene expression for GnRH-R2 mRNA should have been high and should have accumulated for several months (from March to May), prior to the mature oocyte stage. Interestingly, the GnRHR2 mRNA transcripts exhibited three peaks in the ovary (Fig. 4) indicating that GnRH-R2 may be closely related to oocyte development and maturation, and post-spawning. In Odontesthes bonariensis, several subtypes of GnRH receptors in the pituitary also had transient peaks in concentration from January to March [38, 39]. In contrast, in masu salmon, the amounts of GnRH peptide in the pituitary gradually increased with gonad maturation, from spring to autumn $[39,40]$. This would then have promoted fish to migrate from the estuary up to the Yangtze River from March to July.

The mechanism by which GnRH-R2 regulates the spawning migration is still unclear and further research is needed. sGnRH neurons have been shown to help control the PG-axis in maturing adult salmon in the summer [41]. Therefore, sGnRH gene expression is likely to increase before any elevations in the PG-axis activity of chum salmon in the summer, in the Bering Sea [38]. The present study shows that gene expression of GnRH-R2 was elevated in association with the activation of the PG-axis, during the upstream migration of $C$. nasus (Fig. 4). These results support the seasonal profiles of GnRH-R2 mRNA levels in C. nasus are likely to be similar to sGnRH change patterns found in chum salmon [38].
Several studies have measured brain or ovary GnRHR2 proteins by IHC, during gonad maturation [18]. It is thought that only one form of GnRH-R2, with neurons located in the preoptic area, regulates secretion of gonadotropins in the pituitary, although two or three forms of the $\mathrm{GnRH}$ molecule can exist within the same species [42]. The IHC results of the present study revealed higher expression levels of GnRH-R2 in the olfactory bulb upper cells, stratum granular cells and early stage germ cells, including the primary oocytes, in abundance from the beginning of spawning migration [37]. There was weak or no expression in neurogliocytes and mature oocytes. These findings are supported by data from other species and indicate that the GnRH-R2 protein is mainly needed at the onset of migration behavior [37]. The GnRH-R2 protein was also found abundant in the cytoplasm of the germ cells during their developmental and multiplication stages; this suggests that the cytoplasmic protein assembling machinery, through which additional proteins needed for cell division are generated, is very active during those stages. In this sense, it is likely that GnRH-R2 modulates spawning migration in $C$. nasus by both regulating cytoplasmic organization in the germ cells and stimulating the synthesis and release of gonad hormones during the different spawning stages.

\section{Conclusions}

The present study provided evidence that the GnRH-R2 gene expression and protein distribution in the brain and ovaries changed in association with the migratory behavior. The results indicated that GnRH-R2 could act as a mediator; promoting spawning behavior in the anadromous teleost fish $C$. nasus. However, the present study was conducted under natural spawning conditions. The photoperiod and/or water temperature changes could stimulate or delay the maturation of $C$. nasus ovaries. Thus, further study of the influence of environmental factors that regulate gonad maturation and spawning migration in C. nasus are needed. To conclude that GnRH-R2 are functionally involved in gonadal maturation or spawning behavior in the C. nasus, it is necessary to comprehensively examine the effects of GnRH-R2 on the PG-axis neurohormones synthesis and release both in vivo and in vitro.

\section{Abbreviations \\ BW: Body weights; CV: Coefficients of variation; ELISA: Enzyme-linked immuno sorbent assay; GnRH: Gonadotropin-releasing hormone; GnRH-R2: Gonadotropin releasing hormones receptor 2; GSI: The gonadosomatic index; H\&E: Hematoxylin and Eeosin; IHC: Immunohistochemistry; OB: Olfactory bulb; PBS: Phosphate- buffered saline; PG: Pituitary-gonad axis; RT: Room temperature; SG: Stratum granulare; WW: Wet weight}

\section{Acknowledgments}

We thank all funds supporting the experiment and all coauthors devoting their time to the manuscript. 


\section{Funding}

This work was supported by funds from the Public Welfare Agricultural Scientific Research (201203065), Key Laboratory of Freshwater Animal Breeding in Ministry of Agriculture (2015PY076) and the National Natural Science Foundation of China for Young Scientists (31302169).

\section{Availability of data and materials}

Data supporting the manuscript's findings can be found in the manuscript. And the gene related data can be found in the NCBI with the GenBank accession numbers KU861569.

\section{Authors' contributions}

D-AF was responsible for data scoring and analysis, and writing the manuscript. J-RD, Y-FZ, D-PX, M-YZ and KL helped selecting the fish sample, RNA extraction and data analysis during manuscript preparation. PX and D-PL contributed to conceive and edit the manuscript. All authors have read and approved the final manuscript.

\section{Competing interests}

The authors declare that they have no competing interests.

\section{Consent for publication}

All authors read the manuscript thoroughly and consent to submit the manuscript to the journal of BMC Developmental Biology.

\section{Ethics approva}

All fish experimental procedures were performed in accordance with the Regulations for the Administration of Affairs Concerning Experimental Animals and fish sampling were approved and authorized by the Yangtze River Fish Committee in China.

Received: 21 July 2016 Accepted: 6 November 2016

\section{Published online: 24 November 2016}

\section{References}

1. Roch GJ, Busby ER, Sherwood NM. GnRH receptors and peptides: skating backward. Gen Comp Endocrinol. 2014;209:118-34

2. Abe H, Oka Y: Neuromodulatory Functions of Terminal Nerve-GnRH Neurons. Fish Physiology. 2006;25(06):455-503.

3. Kim NN, Shin HS, Habibi HR, Lee J, Choi CY. Expression profiles of three types of $\mathrm{GnRH}$ during sex-change in the protandrous cinnamon clownfish, amphiprion melanopus: effects of exogenous GnRHs. Comp Biochem Physiol Part B Biochem Mol Biol. 2012;161(2):124-33.

4. Alvarado MV, Carrillo M, Felip A. Expression of kisspeptins and their Receptors, gnrh-1/gnrhr-II-1a and gonadotropin genes in the brain of adult male and female European sea bass during different gonadal stages. Gen Comp Endocrinol. 2013:187:104-16.

5. Drori S, Ofir M, Levavi-Sivan B, Yaron Z. Spawning induction in common carp (Cyprinus carpio) using pituitary extract or $\mathrm{GnRH}$ superactive analogue combined with metoclopramide: analysis of hormone profile, progress of oocyte maturation and dependence on temperature. Aquaculture. 1994;119(4):393-407.

6. Marte CL, Sherwood NM, Crim LW, Harvey B. Induced spawning of maturing milkfish (Chanos chanos Forsskal) with gonadotropin-releasing hormone $(\mathrm{GnRH})$ analogues administered in various ways. Aquaculture. 1987;60(3-4):303-10.

7. Mikolajczyk T, Chyb J, Sokolowska-Mikolajczyk M, Enright WJ, Epler P, Filipiak $\mathrm{M}$, Breton B. Attempts to induce an LH surge and ovulation in common carp (Cyprinus carpio L.) by differential application of a potent $\mathrm{GnRH}$ analogue, azagly-nafarelin, under laboratory, commercial hatchery, and natural conditions. Aquaculture. 2003;223(1-4):141-57.

8. Mateos J, Mañanos E, Carrillo M, Zanuy S. Regulation of follicle-stimulating hormone (FSH) and luteinizing hormone (LH) gene expression by gonadotropin-releasing hormone $(\mathrm{GnRH})$ and sexual steroids in the Mediterranean Sea bass. Comp Biochem Physiol Part B Biochem Mol Biol. 2002;132(1):75-86

9. Hildahl J, Taranger GL, Norberg B, Haug TM, Weltzien F-A. Differential regulation of $\mathrm{GnRH}$ ligand and receptor genes in the brain and pituitary of Atlantic cod exposed to different photoperiod. Gen Comp Endocrinol. 2013;180:7-14
10. Hildahl J, Sandvik GK, Edvardsen RB, Fagernes C, Norberg B, Haug TM, Weltzien F-A. Identification and gene expression analysis of three $\mathrm{GnRH}$ genes in female Atlantic cod during puberty provides insight into $\mathrm{GnRH}$ variant gene loss in fish. Gen Comp Endocrinol. 2011;172(3):458-67.

11. Jodo A, Kitahashi T, Taniyama S, Ueda H, Urano A, Ando H. Seasonal changes in expression of genes encoding five types of gonadotropinreleasing hormone receptors and responses to $\mathrm{GnRH}$ analog in the pituitary of masu salmon. Gen Comp Endocrinol. 2005;144(1):1-9.

12. Levavi-Sivan B, Avitan A. Sequence analysis, endocrine regulation, and signal transduction of $\mathrm{GnRH}$ receptors in teleost fish. Gen Comp Endocrinol. 2005;142(1-2):67-73.

13. Lin C-J, Wu G-C, Lee M-F, Lau E-L, Dufour S, Chang C-F. Regulation of two forms of gonadotropin-releasing hormone receptor gene expression in the protandrous black porgy fish, Acanthopagrus schlegeli. Mol Cell Endocrinol. 2010;323(2):137-46.

14. Choi YJ, Kim NN, Habibi HR, Choi CY. Effects of gonadotropin inhibitory hormone or gonadotropin-releasing hormone on reproduction-related genes in the protandrous cinnamon clownfish, Amphiprion melanopus. Gen Comp Endocrinol. 2016:235:89-99.

15. Kaiser UB, Zhao D, Cardona GR, Chin WW. Isolation and characterization of CDNAs encoding the rat pituitary gonadotropin-releasing hormone receptor. Biochem Biophys Res Commun. 1993;189(3):1645-52.

16. Tsutsumi M, Zhou W, Millar R, Mellon P, Roberts J, Flanagan C, Dong K, Gillo $B$, Sealfon S. Cloning and functional expression of a mouse gonadotropinreleasing hormone receptor. Mol Endocrinol. 1992;6(7):1163-9.

17. Tensen C, Okuzawa K, Blomenröhr M, Rebersi F, Leurs R, Bogerd J, Schulz R, Goos H. Distinct Efficacies for Two Endogenous Ligands on a Single Cognate Gonadoliberin Receptor. Eur J Biochem. 1997;243(1-2):134-40

18. Okuzawa K, Kumakura N, Mori A, Gen K, Yamaguchi S, Kagawa H. Regulation of $\mathrm{GnRH}$ and its receptor in a teleost, red seabream. Prog Brain Res. 2002:141:95-110.

19. Piazza Y, Pandolfi M, Da Cuña R, Genovese G, Lo Nostro F. Endosulfan affects $\mathrm{GnRH}$ cells in sexually differentiated juveniles of the perciform Cichlasoma dimerus. Ecotoxicol Environ Saf. 2015;116:150-9.

20. Liu D, Li Y, Tang W, Yang J, Guo H, Zhu G, Li H. Population structure of Coilia nasus in the Yangtze River revealed by insertion of short interspersed elements. Biochem Syst Ecol. 2014;54:103-12.

21. Song R, Li WX, Wu SG, Zou H, Wang GT. Population genetic structure of the acanthocephalan acanthosentis cheni in anadromous, freshwater, and landlocked stocks of its fish host, Coilia nasus. J Parasitol. 2014;100(2):193-7.

22. Haacke C, Hess M, Melzer RR, Gebhart H, Smola U. Fine structure and development of the retina of the grenadier anchovy Coilia nasus (Engraulididae, Clupeiformes). J Morphol. 2001;248(1):41-55.

23. Li WX, Song R, Wu SG, Zou H, Nie P, Wang GT. Seasonal occurrence of helminths in the anadromous fish Coilia nasus (engraulidae): parasite indicators of fish migratory movements. J Parasitol. 2011:97(2):192-6.

24. Zheng F, Guo H-Y, Tang W-Q, Li H-H, Liu D, Liu Z-Z. Age structure and growth characteristics of anadromous populations of coilia nasus in the yangtze River. Chinese J Zool. 2012;47(5):24-31.

25. Duan J-R, Zhou Y-F, Xu D-P, Zhang M-Y, Liu K, Shi Y, Wei Q-W, Fang D-A. Ovary transcriptome profiling of Coilia nasus during spawning migration stages by Illumina sequencing. Mar Genomics. 2015:21:17-9.

26. He W, Li Z, Liu J, Li Y, Murphy BR, Xie S. Validation of a method of estimating age, modelling growth, and describing the age composition of Coilia mystus from the Yangtze Estuary, China. ICES J Mar Sci J du Conseil. 2008;65(9):1655-61.

27. Zhong Y, Power G. Environmental impacts of hydroelectric projects on fish resources in China. Regul Rivers: Res Manage. 1996;12(1):81-98.

28. Wen H-B, Zhang C-X, Xu G-C, Gu R-B, Xu P. Development of Gonads in Coilia nasus from the Yangtze River and Artificial Pond. Chinese J Zool. 2009:44(4):111-7.

29. Xu G-C, Xu P, Gu R-B, Zhang C-X, Zheng J-I. Feeding habits and growth characteristics of pond-cultured Coilia nasus fingerlings. Shengtaixue Zazhi. 2011;30(9):2014-8

30. Liu D, Guo H-Y, Tang W-Q, Yang J-Q. Comparative Evolution of S7 Intron 1 and Ribosomal Internal Transcribed Spacer in Coilia nasus (Clupeiformes: Engraulidae). Int J Mol Sci. 2012;13(3):3085-100.

31. Yang Q, Gao T, Liu J-X. Development and characterization of 17 microsatellite loci in an anadromous fish Coilia nasus. Conserv Genet Resourc. 2014;6(2):357-9. 
32. Tang W, Hu X, Yang J. Species validities of Coilia brachygnathus and Cnasus taihuensis based on sequence variations of complete mtDNA control region. Shengwu Duoyangxing. 2007;15(3):224-31.

33. Yang Q, Gao T, Miao Z. Differentiation between populations of Japanese grenadier anchovy (Coilia nasus) in Northwestern Pacific based on ISSR markers: Implications for biogeography. Biochem Syst Ecol. 2011:39(4-6):286-96.

34. Li Y, Xie S, Li Z, Gong W, He W. Gonad development of an anadromous fish Coilia ectenes (Engraulidae) in lower reach of Yangtze River, China. Fisheries Sci. 2007;73(6):1224-30.

35. Altschul SF, Madden TL, Schäffer AA, Zhang J, Zhang Z, Miller W, Lipman DJ. Gapped BLAST and PSI-BLAST: a new generation of protein database search programs. Nucleic Acids Res. 1997;25(17):3389-402.

36. Livak KJ, Schmittgen TD. Analysis of relative gene expression data using real-time quantitative $P C R$ and the $2-\Delta \Delta C T$ method. Methods. 2001;25(4):402-8

37. Peñaranda DS, Mazzeo I, Hildahl J, Gallego V, Nourizadeh-Lillabadi R, Pérez L, Asturiano JF, Weltzien F-A. Molecular characterization of three GnRH receptor paralogs in the European eel, Anguilla anguilla: Tissue-distribution and changes in transcript abundance during artificially induced sexual development. Mol Cell Endocrinol. 2013;369(1-2):1-14.

38. Onuma TA, Makino K, Ando H, Ban M, Fukuwaka M-A, Azumaya T, Urano A. Expression of GnRH genes is elevated in discrete brain loci of chum salmon before initiation of homing behavior and during spawning migration. Gen Comp Endocrinol. 2010;168(3):356-68.

39. Fukaya K, Amano M, Ueda H. Diurnal changes in salmon GnRH secretion in the brain of masu salmon (Oncorhynchus masou). Gen Comp Endocrinol. 2013;192:77-80.

40. Amano M, Kitamura S, Ikuta K, Suzuki Y, Aida K. Activation of Salmon GnRH mRNA Expression Prior to Differentiation of Precocious Males in Masu Salmon. Gen Comp Endocrinol. 1997;105(3):365-71.

41. Amano M, Okubo K, Ikuta K, Kitamura S, Okuzawa K, Yamada H, Aida K, Yamamori K. Ontogenic origin of salmon GnRH neurons in the ventral telencephalon and the preoptic area in masu salmon. Gen Comp Endocrinol. 2002:127(3):256-62.

42. Holland MCH, Gothilf Y, Meiri I, King JA, Okuzawa K, Elizur A, Zohar Y. Levels of the Native Forms of GnRH in the Pituitary of the Gilthead Seabream, Sparus aurata, at Several Characteristic Stages of the Gonadal Cycle. Gen Comp Endocrinol. 1998:112(3):394-405.

\section{Submit your next manuscript to BioMed Central and we will help you at every step:}

- We accept pre-submission inquiries

- Our selector tool helps you to find the most relevant journal

- We provide round the clock customer support

- Convenient online submission

- Thorough peer review

- Inclusion in PubMed and all major indexing services

- Maximum visibility for your research

Submit your manuscript at wuw biomedcentral.com/submit

) Biomed Central 